\title{
Multidrug-Resistant Listeria Species Shows Abundance in Environmental Waters of a Key District Municipality in South Africa
}

\author{
Liyabona Mpondo ${ }^{1,2, *(\mathbb{D})}$, Kingsley Ehi Ebomah ${ }^{1,2} \mathbb{D}$ and Anthony Ifeanyi Okoh ${ }^{1,2}(\mathbb{D})$ \\ 1 SAMRC Microbial Water Quality Monitoring Centre, University of Fort Hare, Alice 5700, South Africa; \\ kebomah@ufh.ac.za (K.E.E.); aokoh@ufh.ac.za (A.I.O.) \\ 2 Applied and Environmental Microbiology Research Group (AEMREG), Department of Biochemistry and \\ Microbiology, University of Fort Hare, Alice 5700, South Africa \\ * Correspondence: liyampondo@gmail.com; Tel.: +27-614-796-783
}

Citation: Mpondo, L.; Ebomah, K.E.; Okoh, A.I. Multidrug-Resistant Listeria Species Shows Abundance in Environmental Waters of a Key District Municipality in South Africa. Int. J. Environ. Res. Public Health 2021, 18, 481. https://doi.org/10.3390/ ijerph18020481

Received: 10 November 2020 Accepted: 3 January 2021 Published: 8 January 2021

Publisher's Note: MDPI stays neutral with regard to jurisdictional clai$\mathrm{ms}$ in published maps and institutional affiliations.

Copyright: (C) 2021 by the authors. Licensee MDPI, Basel, Switzerland. This article is an open access article distributed under the terms and conditions of the Creative Commons Attribution (CC BY) license (https:// creativecommons.org/licenses/by/ $4.0 /)$.

\begin{abstract}
The prevalence of bacteria with multidrug-resistance (MDR) is a significant threat to public health globally. Listeria spp. are naturally ubiquitous, with L. monocytogenes particularly being ranked as important foodborne disease-causing microorganisms. This study aimed to evaluate the incidence and determine the antimicrobial resistance (AMR) profiles of multidrug-resistant Listeria spp. (MDRL) isolated from different environmental samples (river and irrigation water) in the Sarah Baartman District Municipality (SBDM), Eastern Cape Province (ECP), South Africa. Molecular identification and characterization were carried out using polymerase chain reaction (PCR) and isolates that exhibited phenotypic resistance were further screened for relevant antimicrobial-resistant genes (ARGs). Findings revealed a total of 124 presumptive Listeria isolates; 69 were molecularly confirmed Listeria species. Out of the confirmed species, 41 isolates (59\%) were classified as L. monocytogenes while $9(13 \%)$ were classified as L. welshimeri. All Listeria spp. exhibited phenotypic resistance against ampicillin, penicillin, and trimethoprim-sulphamethoxazole and further screening revealed ARGs in the following proportions: sulI (71\%), bla $a_{T E M}(66 \%)$, tet $A(63 \%)$, and $b l a_{C I T}(33 \%)$. Results confirmed the occurrence of ARGs among Listeria inhabiting surface waters of ECP. The present study indicates that the river water samples collected from SBDM are highly contaminated with MDRL, hence, constituting a potential health risk.
\end{abstract}

Keywords: antimicrobial-resistant gene; L. monocytogenes; Listeria; multidrug-resistance; public health

\section{Introduction}

Genus Listeria is made up of a group of small rod-shaped, non-spore-forming, facultative anaerobic microorganisms that belong to the family Listeriaceae. These bacterial species are motile and capable of thriving at low temperatures and in harsh conditions [1,2]. The genus Listeria contains 20 major species including L. welshimeri, L. grayi, L. marthii, L. seeligeri, L. ivanovii, L. innocua, and L. monocytogenes and these microbes are present within various environmental niches including soil, vegetables, water, wastewater, and animal feces [3]. Many studies have investigated the occurrence of Listeria species in different environmental sources such as soil [4-6], while other studies reported on farm samples [7], livestock along with ready-to-eat (RTE) food products [8-11]. Additionally, some other studies have investigated the prevalence of Listeria in wastewater treatment plants (WWTPs) suggesting that these pathogens can thrive even after chlorination [12-15]. Among the common Listeria spp., L. ivanovii and L. monocytogenes are both considered as relevant animal and human pathogens. However, L. monocytogenes is regarded as the third most common foodborne pathogen causing infections in individuals with higher risk, for instance, elderly and immune-compromised people, as well as pregnant women [16]. These infections can lead to a potentially critical and fatal illness known as listeriosis, with 
extreme cases bringing about symptoms such as meningitis and septicemia in addition to abortion and/or miscarriage in pregnant women [17].

The World Health Organization (WHO) ranked listeriosis among the deadliest foodborne diseases with a $20 \%$ to $30 \%$ mortality rate [18]. L. monocytogenes is a transitory resident of the intestinal tract in humans, with about $10 \%$ of the world's population reported to be carriers of the microorganisms without experiencing any apparent symptoms $[19,20]$. According to a report by Jemmi and Stephan [21], listeriosis was responsible for a high rate of hospitalization in the United States of America (USA), with post-2009 reports from Europe indicating similar hospitalization rates compared to those reported by the aforementioned study. Furthermore, Listeria spp. harboring antibiotic resistance genes (ARGs) have been detected in agricultural samples [22] and the emergence of antibiotic-resistant L. monocytogenes (ARLM) has also been reported subsequently $[17,23,24]$.

Although multidrug-resistant Listeria spp. (MDRL) have rarely been reported, antibioticresistant Listeria (ARL) was first reported from a French patient diagnosed with meningoencephalitis in 1988. A recent study disclosed isolates exhibiting phenotypic resistance against streptomycin, chloramphenicol, tetracycline, and erythromycin [16]. Other studies have reported ARL exhibiting resistance against antimicrobials such as aminoglycosides, betalactams, chloramphenicol, and also sulphonamides [25,26]. Thus, ARL has also become an increasing One Health concern that heightens the antibiotic resistance challenges faced globally, further undermining progress in healthcare, food production, and life expectancy posing health risks to not only humans but also animals and the environment [27].

In 2011, the Centers for Disease Control and Prevention (CDC) reported an outbreak of listeriosis that was associated with contaminated cantaloupe melons in Colorado, USA which led to 147 cases, out of which 142 were hospitalized, causing 33 fatalities [28]. Recently, CDC reported a multistate outbreak of L. monocytogenes infection in the Republic of Korea. The outbreak was linked to commercially bought enoki mushrooms and was responsible for 36 reported cases, 31 hospitalizations, and 4 fatalities [29]. A report by the National Institute of Communicable Diseases stated that in 2018, the South African government reported an outbreak of about 1053 listeriosis cases that was responsible for more than 200 deaths nationwide in which 10 of those fatalities were reported to be from the Eastern Cape Province [30]. Polony, a ready-to-eat (RTE) product, was implicated as the source of the bacterium by whole-genome sequencing (WGS) [30,31]. Human health is linked with the health of animals and the shared environment through the One Health Approach [32]. Therefore, the presence of L. monocytogenes in water sources, particularly those used for irrigation and consumption, may lead to the carry-over of potential pathogens from the water source to fresh produce. Upon consumption of contaminated food or drinking water, infectious doses of the bacterium may manifest in either febrile listerial gastroenteritis (non-invasive listeriosis) or invasive listeriosis associated with the aforementioned symptoms [17]. Presently, there is a scarcity of data on the incidence and antibiogram fingerprints of Listeria spp. recovered from the aquatic milieu in South Africa. This is one of the few studies within the Eastern Cape Province (ECP) that aimed to evaluate the occurrence, as well as delineate the antibiogram profiles of Listeria spp. isolates recovered from river water and irrigation water sources collected from the Sarah Baartman District Municipality (SBDM) in South Africa.

\section{Materials and Methods}

\subsection{Description of the Study Area and Sample Collection}

This study was conducted in the SBDM (geographical coordinates: $33^{\circ} 57^{\prime} 00^{\prime \prime}$ S; $25^{\circ} 36^{\prime} 00^{\prime \prime}$ E) situated in the ECP, South Africa. The sampling sites were the Great Fish River and the Bloukrans River. These rivers flow south and are tributaries of the Kowie River situated near Grahamstown. The Bloukrans River serves different purposes such as irrigation water for nearby farms and also has other functions for livestock farms. The river also serves as a receiving watershed for final effluent discharge from the district's WWTP. Water samples were collected downstream from the Bloukrans River and farm samples 
(specifically irrigation water) from some farms in the SBDM. Six samples were collected on a once-off regime in the month of September. Water samples were collected accordingly in duplicates by means of sterile bottles (1-L) and conveyed in an ice-box to the laboratory for bacteriological analysis in no more than six hours of collection.

\subsection{Processing of Samples}

For bacteriological analysis, the standard filtration method was followed as described by Olaniran et al. [15] with modification. The water samples $(100 \mathrm{~mL})$ were filtered via membrane filter papers $(0.45-\mu \mathrm{m}$ pore size) (Merck, South Africa) with the aid of a vacuum pump. For enumeration of the Listeria spp., each membrane filter was aseptically picked with sterilized forceps and transferred onto the surface of Chromogenic Listeria agar (ISO) Base (Oxoid Limited, Basingstoke, UK) mixed with one vial of OCLA (ISO) selective supplement and OCLA (ISO) differential supplement (Oxoid Ltd., Basingstoke, UK). This followed the standards as described previously by Ottaviani and Agosti (ALOA) in ISO 11290-1:1997 used for enumerating Listeria spp. including L. monocytogenes [33]. The media plates were incubated for $24 \mathrm{~h}$ at $37^{\circ} \mathrm{C}$. After the incubation, blue/green colonies with no halo were considered as unconfirmed Listeria spp. on the ISO Base. The data were converted to $\log _{10}$ CFU per $100 \mathrm{~mL}$ [34].

\subsection{Isolation of Listeria spp. by Enrichment}

Due to the slight turbidity of the river and irrigation water samples collected, enrichment was carried out to increase the detection of Listeria spp. by inserting the membrane filter into $90 \mathrm{~mL}$ of Tryptic Soy Broth (TSB) and afterward incubated aerobically at $37^{\circ} \mathrm{C}$ for 16-18 h (Laboratorios CONDA, Madrid, Spain). Following incubation, the second enrichment was done by aseptically transferring $1 \mathrm{~mL}$ of the enriched TSB suspension onto $9 \mathrm{~mL}$ of Fraser Broth (Oxoid Ltd., Basingstoke, UK), vortexed, and then incubated at $37^{\circ} \mathrm{C}$

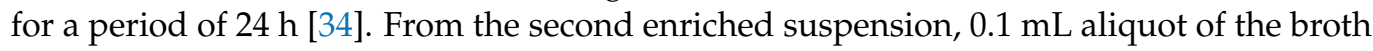
was spread onto Chromogenic Listeria agar (LCA) (Oxoid Ltd., UK), thereafter supplemented using OCLA (ISO) selective supplement with OCLA (ISO) differential supplement, following the standards as defined by Ottaviani and Agosti (ALOA) in ISO 11290-1:1997 and incubated aerobically for $24 \mathrm{~h}$ at $37^{\circ} \mathrm{C}$. After incubation, presumptive Listeria isolates (showing blue/green colonies either with or without halos) were subsequently purified onto nutrient agar (NA) (Oxoid Ltd., Basingstoke, UK) and incubation conditions of $37^{\circ} \mathrm{C}$ for a period of $24 \mathrm{~h}$ were followed. Pure colonies were further inoculated in sterile nutrient broth (NB) following an incubation period of $18-24 \mathrm{~h}$ at $37^{\circ} \mathrm{C}$. The overnight culture was stored in $25 \%$ glycerol stock and kept in a freezer at $-80^{\circ} \mathrm{C}$ for further analysis.

\subsection{DNA Extraction}

The boiling method was employed to extract bacterial DNA following the methods described by Maugeri et al. [35]. The presumptive isolates were resuscitated by inoculation into NB and an incubation period of $18-24 \mathrm{~h}$ at $37^{\circ} \mathrm{C}$ was followed. A loopful from the NB culture was suspended in $200 \mu \mathrm{L}$ of sterile distilled water contained in $1.5 \mathrm{~mL}$ Eppendorf tubes and vortexed. For $15 \mathrm{~min}$, the suspension was heated at $100{ }^{\circ} \mathrm{C}$ in an MS2 Dri-Block DB.2A instrument (Techne, Marshalltown, South Africa) to break down the bacterial cells. After heating, the suspension was then centrifuged (at 10,000 rpm for $10 \mathrm{~min}$ ) in order to take away the cell debris from the DNA material confined within the supernatant. Thereafter, the lysate supernatant was employed as a DNA template in the polymerase chain reaction (PCR) technique.

\subsection{Molecular Identification of Presumptive Listeria Isolates}

The presumptive Listeria isolates were molecularly confirmed using the PCR technique. Table 1 summarizes the set of primers of target Listeria species, their respective PCR product sizes, and PCR conditions. 
Table 1. List of primers of target Listeria species, respective amplicon sizes, and the polymerase chain reaction (PCR) cycling conditions.

\begin{tabular}{|c|c|c|c|c|c|}
\hline Species & Gene Target & $\begin{array}{l}\text { Primer Sequence } \\
\qquad\left(5^{\prime} \rightarrow 3^{\prime}\right)\end{array}$ & $\begin{array}{l}\text { Cycling } \\
\text { Conditions }\end{array}$ & $\begin{array}{l}\text { Amplicon } \\
\text { Size (bp) }\end{array}$ & Reference \\
\hline Listeria spp. & prs & $\begin{array}{l}\text { F-GCT GAA GAG ATT GCG AAA GAAG } \\
\text { R-CAA AGA AAC CTT GGA TTT GCGG }\end{array}$ & $\begin{array}{c}94^{\circ} \mathrm{C}, 94^{\circ} \mathrm{C}, 60^{\circ} \mathrm{C}, \\
72{ }^{\circ} \mathrm{C}, 72{ }^{\circ} \mathrm{C} \\
3^{\prime}, 1^{\prime}, 2^{\prime}, 1^{\prime}, 15^{\prime}\end{array}$ & 370 & [36] \\
\hline L. monocytogenes & $\operatorname{prf} A$ & $\begin{array}{l}\text { F-GATACAGAAACATCGGTTGGC } \\
\text { R-GTGTAATCTTGATGCCATCAG }\end{array}$ & $\begin{array}{c}94^{\circ} \mathrm{C}, 94^{\circ} \mathrm{C}, 56^{\circ} \mathrm{C}, \\
72^{\circ} \mathrm{C}, 72^{\circ} \mathrm{C} \\
5^{\prime}, 45^{\prime \prime}, 30^{\prime \prime}, 1^{\prime}, 5^{\prime}\end{array}$ & 274 & [37] \\
\hline L. welshimeri & $\begin{array}{l}\text { iap-F } \\
L W-R\end{array}$ & $\begin{array}{l}\text { F-ATGAATATGAAAAAAGCAAC } \\
\text { R-GTGCAGGCGCTGGAGCC }\end{array}$ & $\begin{array}{c}94^{\circ} \mathrm{C}, 94^{\circ} \mathrm{C}, 52{ }^{\circ} \mathrm{C}, \\
72{ }^{\circ} \mathrm{C}, 72{ }^{\circ} \mathrm{C} \\
4^{\prime}, 20^{\prime \prime}, 30^{\prime \prime}, 1^{\prime}, 5^{\prime}\end{array}$ & 919 & [10] \\
\hline
\end{tabular}

' represents minutes " represents seconds.

\subsection{Antimicrobial Susceptibility Test (AST) of the Molecularly Identified Listeria Species}

All the identified Listeria species were put through AST using 15 panels of antibiotics as described by the Kirby-Bauer disc diffusion technique. The results were interpreted accordingly following the Clinical and Laboratory Standards Institute [38] guidelines. Fifteen test antibiotics (Davies Diagnostics (Pty) Limited, South Africa) were selected across 10 families of antimicrobials: aminoglycosides: gentamicin $(10 \mu \mathrm{g})$, amikacin $(30 \mu \mathrm{g})$; betalactams: ampicillin $(25 \mu \mathrm{g})$, oxacillin $(1 \mu \mathrm{g})$, penicillin $\mathrm{G}(10 \mu \mathrm{g})$; cephems: cephalothin $(30 \mu \mathrm{g})$; fluoroquinolones: levofloxacin $(5 \mu \mathrm{g})$, ciprofloxacin $(5 \mu \mathrm{g})$; quinolones: nalidixic acid $(30 \mu \mathrm{g})$, sulphonamides: trimetroprim-sulphamethoxazole $(25 \mu \mathrm{g})$; phenicols: chloramphenicol $(30 \mu \mathrm{g})$; tetracycline: tetracycline $(30 \mu \mathrm{g})$; lincosamide: clindamycin $(2 \mu \mathrm{g})$; macrolides: erythromycin $(15 \mu \mathrm{g})$ and vancomycin $(30 \mu \mathrm{g})$. Approximately $100-200 \mathrm{~mL}$ of the overnight bacterial broth culture was poured into $5 \mathrm{~mL}$ normal saline solution and then standardized using the $0.5 \mathrm{McF}$ arland standard. Subsequently, $100 \mathrm{~mL}$ was evenly spread on Mueller-Hinton agar (MHA) (Merck, Modderfontein, South Africa) plates using a sterile glass spreader, and the MHA plates were left to dry a little before being immersed with the aforementioned antibiotic discs, then incubated at $37^{\circ} \mathrm{C}$ for $24 \mathrm{~h}$. Afterward, the interpretative zones of diameter for Staphylococcus spp. were referred to in this study because the interpretative criteria for Listeria spp. are unavailable in the CLSI guidelines [39].

\subsection{Multiple Antibiotic-Resistance Phenotypes (MARPs) and Multiple Antibiotic-Resistance Index (MARI)}

The MARPs pattern of antimicrobial-resistant Listeria species (ARLS) was generated based on isolates that exhibited phenotypic antibiotic resistance (AR) to 3 or more antimicrobial agents as described by Krumperman [40], MARI was also determined for each isolate. MARI values were calculated using the mathematical formula:

$$
M A R \text { Index }=a / b
$$

where " $a$ " denotes the sum of test antibiotics the isolates displayed resistance to; " $b$ " denotes the total sum of antimicrobial agents used.

\subsection{Molecular Characterization of the Relevant Antimicrobial-Resistant Genes}

The PCR profiling of antimicrobial resistance (AMR) determinants of ARLS involved the screening of 10 antimicrobial-resistant genes (ARGs) encoding for relevant $\beta$-lactamases following the method previously described by Dallenne et al. [41]. Table 2 summarizes the primers used and amplification conditions for the detection of extended-spectrum beta-lactamases (ESBL) ARGs. The $\beta$-lactamases assay comprised of one singleplex PCR for the detection of cefotaximase-Munich (CTX-M) group 8/25 and three multiplex PCR assay, which include multiplex I PCR for detection of Temoneira (TEM), sulphadryl variable (SHV) and oxacillinase (OXA) $\beta$-lactamase; multiplex II PCR is for the detection of plasmid- 
mediated AmpC $\beta$-lactamase types including the forkhead-box (FOX) group, Citron RhoInteracting Serine/Threonine Kinase and the chromosomal EBC family; multiplex III PCR for the detection of carbapenemase including Klebsiella pnuemoniae carbapenemase (KPC), Verona integon-encoded metallo-beta-lactamase (VIM) and active-on-imipenem (IMI) genes. A total of 14 ARGs were screened using the PCR technique. Table 3 summarizes the list of primers for the screening of relevant ARGs.

Table 2. Set of primers and amplification conditions for the detection of extended-spectrum beta-lactamases (ESBL) antimicrobial-resistant genes (ARGs).

\begin{tabular}{|c|c|c|c|c|c|}
\hline Multiplex Name & Primer & $\begin{array}{l}\text { Amplicon Size } \\
\text { (base pair (bp)) }\end{array}$ & Primer Sequence $\left(5^{\prime}-3^{\prime}\right)$ & Cycling Conditions & Reference \\
\hline $\begin{array}{l}\text { Multiplex I TEM, } \\
\text { SHV, and OXA-1-like }\end{array}$ & $\begin{array}{l}b_{T E M} \\
b l a_{S H V} \\
713\end{array}$ & $\begin{array}{c}800 \\
b l a_{O X A-1} \\
564\end{array}$ & $\begin{array}{l}\text { F: ATTTCCGTGTCGCCCTTATTC } \\
\text { R: CGTTCATCCATAGTTGCCTGAC } \\
\text { F: AGCCGCTTGAGCAAATTAAAC } \\
\text { R: ATCCCGCAGATAAATCACCAC } \\
\text { F: GGCACCAGATTCAACTTTCAAG } \\
\text { R: GACCCCAAGTTTCCTGTAAGTG }\end{array}$ & $\begin{array}{c}94^{\circ} \mathrm{C}, 94^{\circ} \mathrm{C}, 60^{\circ} \mathrm{C}, \\
72^{\circ} \mathrm{C}, 72^{\circ} \mathrm{C} \\
10^{\prime}, 40^{\prime \prime}, 40^{\prime \prime}, 60^{\prime \prime}, 7^{\prime}\end{array}$ & [41] \\
\hline $\begin{array}{l}\text { Multiplex II FOX, } \\
\text { CIT, and EBC }\end{array}$ & $\begin{array}{c}b l a_{F O X} \\
b l a_{C I T} \\
538\end{array}$ & $\begin{array}{c}162 \\
b l a_{E B C} \\
683\end{array}$ & $\begin{array}{c}\text { F: CTACAGTGCGGGTGGTTT } \\
\text { R: CTATTTGCGGCCAGGTGA } \\
\text { F: CGAAGAGGCAATGACCAGAC } \\
\text { R: ACGGACAGGGTTAGGATAGY b } \\
\text { F: CGGTAAAGCCGATGTTGCG } \\
\text { R: AGCCTAACCCCTGATACA }\end{array}$ & $\begin{array}{c}94^{\circ} \mathrm{C}, 94^{\circ} \mathrm{C}, 60^{\circ} \mathrm{C}, \\
72^{\circ} \mathrm{C}, 72^{\circ} \mathrm{C} \\
10^{\prime}, 40^{\prime \prime}, 40^{\prime \prime}, 60^{\prime \prime}, 7^{\prime}\end{array}$ & [41] \\
\hline $\begin{array}{l}\text { Singleplex CTX_M } \\
\text { group } 8 / 25\end{array}$ & $b l a_{C T X-M}$ & 326 & $\begin{array}{l}\text { F: AACRCRCAGACGCTCTAC }{ }^{\mathrm{b}} \\
\text { R: TCGAGCCGGAASGTGTYAT }\end{array}$ & $\begin{array}{c}94^{\circ} \mathrm{C}, 94^{\circ} \mathrm{C}, 60^{\circ} \mathrm{C}, \\
72^{\circ} \mathrm{C}, 72^{\circ} \mathrm{C} \\
10^{\prime}, 40^{\prime \prime}, 40^{\prime \prime}, 60^{\prime \prime}, 7^{\prime}\end{array}$ & [41] \\
\hline $\begin{array}{l}\text { Multiplex III IMP, } \\
\text { VIM, and KPC }\end{array}$ & $\begin{array}{c}b l a_{I M P} \\
b l a_{V I M} \\
390\end{array}$ & $\begin{array}{c}139 \\
b l a_{K P C} \\
538\end{array}$ & $\begin{array}{c}\text { F: TTGACACTCCATTTACDG }{ }^{\text {b }} \\
\text { R: GATYGAGAATTAAGCCACYCT b } \\
\text { F: GATGGTGTTTGGTCGCATA } \\
\text { R: CGAATGCGCAGCACCAG } \\
\text { F: CATTCAAGGGCTTTCTTGCTGC } \\
\text { R: ACGACGGCATAGTCATTTGC }\end{array}$ & $\begin{array}{c}94^{\circ} \mathrm{C}, 94^{\circ} \mathrm{C}, 55^{\circ} \mathrm{C}, \\
72^{\circ} \mathrm{C}, 72^{\circ} \mathrm{C} \\
10^{\prime}, 40^{\prime \prime}, 40^{\prime \prime}, 60^{\prime \prime}, 7^{\prime}\end{array}$ & [41] \\
\hline
\end{tabular}

' represents minutes " represents seconds ${ }^{\mathrm{b}} \mathrm{Y}=\mathrm{T}$ or $\mathrm{C} ; \mathrm{R}=\mathrm{A}$ or $\mathrm{G} ; \mathrm{S}=\mathrm{G}$ or $\mathrm{C} ; \mathrm{D}=\mathrm{A}$ or $\mathrm{G}$ or $\mathrm{T}[41]$.

Table 3. List of primers and amplification conditions for the screening of target ARGs.

\begin{tabular}{|c|c|c|c|c|c|}
\hline Antimicrobial Class & Target Genes & Primer Sequence $\left(5^{\prime}-3^{\prime}\right)$ & Amplicon Size (bp) & $\begin{array}{l}\text { Amplification } \\
\text { Conditions }\end{array}$ & References \\
\hline \multirow[t]{2}{*}{ Sulfonamides } & sul1 & $\begin{array}{l}\text { F: TTCGGCATTCTGAATCTCAC } \\
\text { R:ATGATCTAACCCTCGGTCTC }\end{array}$ & 822 & $\begin{array}{c}94{ }^{\circ} \mathrm{C}, 94^{\circ} \mathrm{C}, 55^{\circ} \mathrm{C}, \\
72^{\circ} \mathrm{C}, 72^{\circ} \mathrm{C} \\
5^{\prime}, 1^{\prime}, 1^{\prime}, 5^{\prime}, 5^{\prime}\end{array}$ & [42] \\
\hline & sulli & $\begin{array}{l}\text { F: CGGCATCGTCAACATAACC } \\
\text { R: GTGTGCGGATGAAGTCAG }\end{array}$ & 625 & $\begin{array}{l}94^{\circ} \mathrm{C}, 94^{\circ} \mathrm{C}, 50^{\circ} \mathrm{C}, \\
72^{\circ} \mathrm{C}, 72^{\circ} \mathrm{C} \\
5^{\prime}, 30^{\prime \prime}, 30^{\prime \prime}, 1^{\prime}, 5^{\prime}\end{array}$ & [43] \\
\hline \multirow[t]{2}{*}{ Beta-lactams } & $\operatorname{ampC}$ & $\begin{array}{l}\text { F: TTCTATCAAMACTGGCARCC } \\
\text { R:CCYTTTTATGTACCCAYGA }\end{array}$ & 550 & $\begin{array}{l}94^{\circ} \mathrm{C}, 94^{\circ} \mathrm{C}, 60^{\circ} \mathrm{C}, \\
72^{\circ} \mathrm{C}, 72^{\circ} \mathrm{C} \\
4^{\prime}, 45^{\prime \prime}, 45^{\prime \prime}, 45^{\prime \prime}, 7^{\prime}\end{array}$ & [44] \\
\hline & $B l a_{T E M}$ & $\begin{array}{l}\text { F: TTTCGTGTCGCCCTTATTCC } \\
\text { R: CCGGCTCCAGATTTATCAGC }\end{array}$ & 690 & $\begin{array}{c}94^{\circ} \mathrm{C}, 94^{\circ} \mathrm{C}, 60^{\circ} \mathrm{C}, \\
72^{\circ} \mathrm{C}, 72^{\circ} \mathrm{C} \\
5^{\prime}, 30^{\prime \prime}, 30^{\prime \prime}, 1.5^{\prime}, 5^{\prime}\end{array}$ & [45] \\
\hline \multirow{4}{*}{ Tetracyclines } & tet $A$ & $\begin{array}{l}\text { F: GCTACATCCTGCTTGCCTTC } \\
\text { R:CATAGATCGCCGTGAAGAGG }\end{array}$ & 201 & \multirow{4}{*}{$\begin{array}{c}94^{\circ} \mathrm{C}, 94^{\circ} \mathrm{C}, 55^{\circ} \mathrm{C}, \\
72^{\circ} \mathrm{C}, 72^{\circ} \mathrm{C} \\
5^{\prime}, 1^{\prime}, 1^{\prime}, 1^{\prime}, 5^{\prime}\end{array}$} & [46] \\
\hline & tet $B$ & $\begin{array}{l}\text { F: TTGGTTAGGGGCAAGTTTTG } \\
\text { R: GTAATGGGCCAATAACACCG }\end{array}$ & 359 & & [46] \\
\hline & tetC & $\begin{array}{l}\text { F: CTTGAGAGCCTTCAACCCAG } \\
\text { R: ATGGTCGTCATCTACCTGCC }\end{array}$ & 418 & & [46] \\
\hline & tet $M$ & $\begin{array}{l}\text { F: AGT GGA GCG ATT ACA GAA } \\
\text { R:CAT ATG TCC TGG CGT GTC TA }\end{array}$ & 158 & & [46] \\
\hline Phenicols & catII & $\begin{array}{l}\text { F: ACACTTTGCCCTTTATCGTC } \\
\text { R:TGAAAGCCATCACATACTGC }\end{array}$ & 543 & $\begin{array}{l}94^{\circ} \mathrm{C}, 94^{\circ} \mathrm{C}, 55^{\circ} \mathrm{C}, \\
72^{\circ} \mathrm{C}, 72^{\circ} \mathrm{C} \\
5^{\prime}, 30^{\prime \prime}, 30^{\prime \prime}, 90^{\prime \prime}, 5^{\prime}\end{array}$ & [44] \\
\hline
\end{tabular}


Table 3. Cont.

\begin{tabular}{|c|c|c|c|c|c|}
\hline Antimicrobial Class & Target Genes & Primer Sequence $\left(5^{\prime}-3^{\prime}\right)$ & Amplicon Size (bp) & $\begin{array}{l}\text { Amplification } \\
\text { Conditions }\end{array}$ & References \\
\hline \multirow[t]{5}{*}{ Aminoglycosides } & str $A$ & $\begin{array}{l}\text { F: CTTGGTGATAACGGCAATTC } \\
\text { R:CCAATCGCAGATAGAAGGC }\end{array}$ & 348 & \multirow{2}{*}{$\begin{array}{c}94^{\circ} \mathrm{C}, 94^{\circ} \mathrm{C}, 55^{\circ} \mathrm{C}, \\
72^{\circ} \mathrm{C}, 72^{\circ} \mathrm{C} \\
4^{\prime}, 45^{\prime \prime}, 45^{\prime \prime}, 45^{\prime \prime}, 7^{\prime}\end{array}$} & [44] \\
\hline & $\operatorname{aad} A$ & $\begin{array}{l}\text { F: GTGGATGGCGGCCTGAAGCC } \\
\text { R: AATGCCCAGTCGGCAGCG }\end{array}$ & 525 & & [44] \\
\hline & $\begin{array}{c}a a c(3)- \\
\operatorname{IIa(aacC2)a}\end{array}$ & $\begin{array}{l}\text { F: CGGAAGGCAATAACGGAG } \\
\text { R: TCGAACAGGTAGCACTGAG }\end{array}$ & 428 & \multirow{3}{*}{$\begin{array}{l}94^{\circ} \mathrm{C}, 94^{\circ} \mathrm{C}, 55^{\circ} \mathrm{C}, \\
72^{\circ} \mathrm{C}, 72^{\circ} \mathrm{C} \\
5^{\prime}, 30^{\prime \prime}, 30^{\prime \prime}, 90^{\prime \prime}, 5^{\prime}\end{array}$} & [42] \\
\hline & $\begin{array}{c}\operatorname{aph}(3)- \\
\operatorname{Ia}(\operatorname{aph} A 1) a\end{array}$ & $\begin{array}{l}\text { F: ATGGGCTCGCGATAATGTC } \\
\text { R: CTCACCGAGGCAGTTCCAT }\end{array}$ & 600 & & [42] \\
\hline & $\begin{array}{l}\operatorname{aph}(3)-I I a \\
(\operatorname{aph} A 2) a\end{array}$ & $\begin{array}{l}\text { F: GAACAAGATGGATTGCACGC } \\
\text { R:GCTCTTCAGCAATATCACGG }\end{array}$ & 510 & & [42] \\
\hline
\end{tabular}

'represents minutes " represents seconds.

\section{Results}

\subsection{Enumeration and Distribution of Presumptive Listeria spp. in Water Samples}

The results showed that the standard plate count for Listeria spp. obtained from the river samples collected from Bloukrans River access point one (BRT) and Bloukrans River access point two (BRD) ranged from 3.49-3.88 $\log _{10}$ CFU/100mL. The standard plate count from Duncan Farm irrigation-water (DFW) samples ranged from 0-3.68 $\log _{10}$ CFU/100mL. Therefore, the dissemination of presumptive Listeria spp. was higher for the BRD sampling site in the SBDM, as compared to the other sampling sites.

\subsection{Molecular Confirmation and Characterization of the Recovered Listeria Isolates}

A total number of 124 unconfirmed Listeria isolates were recovered from the water samples analyzed. The results revealed that 55.7\% (69/124) harbored the prs gene for the confirmation of Listeria spp. (Supplementary Figure S1). Further characterization revealed $59 \%$ (41/69) of the confirmed Listeria isolates were confirmed as L. monocytogenes (Supplementary Figure S2) and 13\% (9/69) were confirmed to be L. welshimeri (Supplementary Figure S3).

\subsection{Antimicrobial Susceptibility Patterns (ASP) of the Confirmed Listeria spp.}

All confirmed Listeria spp. were subjected to antibiogram susceptibility testing. The result showed that besides gentamicin and amikacin which had the lowest percentage resistance of $32 \%$ and 39\%, respectively, the Listeria isolates exhibited resistance $(100 \%)$ against other test antibiotics including penicillin, cephalothin, ciprofloxacin, levofloxacin, trimethoprim-sulphamethoxazole, nalidixic acid, chloramphenicol, tetracycline, erythromycin, vancomycin, clindamycin, and oxacillin. Among the 15 antimicrobial agents, only amikacin and gentamicin had activity against $L$. monocytogenes with a low resistance percentage of 39\% and 32\%, respectively whereas no L. welshimeri isolates exhibited resistance against amikacin. However, L. welshimeri exhibited a resistance of $33 \%$ against gentamicin.

\subsection{MAR patterns and MAR Indices}

The MAR phenotype patterns and MAR indices of Listeria spp. were generated and are summarized in Table 4. Results from the phenotypic resistance profiles of L. monocytogenes show four MAR patterns against the antibiotics (Table 4). The four MARP patterns were generated from 13 to 15 antibiotics. The most frequently observed MARP pattern among the L. monocytogenes was the AP-PG-KF-CIP-LEV-TS-NA-C-T-ERY-VA-CD-OXA pattern with $41.5 \%(17 / 41)$ of the isolates exhibiting the resistance pattern. The MARI values of all L. monocytogenes ranged between 0.87 and 1 (Table 4), which is greater than the 0.2 arbitrary threshold set by Krumperman [40]. MARI values ranging from 0.87 to 0.93 were observed for L. welshimeri, which is greater than the 0.2 threshold (Table 4 ). A total of 
two MARP patterns were observed for L. welshimeri isolates as shown in Table 4; with the most frequently observed MARP pattern being AP-PG-KF-CIP-LEV-TS-NA-C-T-ERY-VACD-OXA, observed amongst $66.7 \%$ of the isolates.

Table 4. MAR patterns of L. monocytogenes isolated from the water samples.

\begin{tabular}{cccc}
\hline No. of Antibiotics & MARP Patterns & No. of Observed & MARI \\
\hline & L. monocytogenes $\mathbf{n}=\mathbf{4 1}$ & 17 & \\
\hline 13 & AP-PG-KF-CIP-LEV-TS-NA-C-T-ERY-VA-CD-OXA & 11 & 8 \\
14 & AK-AP-PG-KF-CIP-LEV -TS-NA-C-T-ERY-VA-CD-OXA & 5 & 0.93 \\
14 & GM-AP-PG-KF-CIP-LEV-TS-NA-C-T-ERY-VA-CD-OXA & 1 \\
\hline 15 & AK-GM-AP-PG-KF-CIP-LEV-TS-NA-C-T-ER-VA-CD-OXA & 6 \\
\hline 13 & L. welshimeri $\mathbf{n}=\mathbf{9}$ & 3 \\
\hline
\end{tabular}

\subsection{PCR Profiling of Antimicrobial Resistance Determinants in Listeria spp.}

The ARGs screened in this study were chosen due to the high percentage of MAR phenotypes exhibited by the confirmed Listeria spp. (Table 4). Isolates were screened for 14 relevant ARGs that belong to five different classes of antibiotics including betalactams, phenicols, sulfonamides, tetracyclines, and aminoglycoside. Additionally, the confirmed isolates were screened for 10 relevant ESBL genes. The percentage occurrence and distribution of ARGs harbored by L. monocytogenes and L. welshimeri are summarized in Table 5.

Table 5. Distribution of ARGs in L. monocytogenes and L. welshimeri isolated from the water samples.

\begin{tabular}{|c|c|c|c|}
\hline Target Antimicrobials & Antimicrobial-Resistant Genes & L. monocytogenes & L. welshimeri \\
\hline Sulfonamides & sulI & $71 \%(29)$ & $67 \%(6)$ \\
\hline \multirow[t]{2}{*}{ Beta Lactams } & $\operatorname{ampC}$ & 0 & 0 \\
\hline & tet $A$ & $63 \%(26)$ & $78 \%(7)$ \\
\hline \multirow{3}{*}{ Tetracyclines } & tet $B$ & 0 & 0 \\
\hline & tet $C$ & 0 & 0 \\
\hline & tetM & 0 & 0 \\
\hline Phenicols & catII & $7 \%(3)$ & 0 \\
\hline \multirow{5}{*}{ Aminoglycosides } & strA & 0 & 0 \\
\hline & $\operatorname{aad} A$ & 0 & 0 \\
\hline & blaTEM & $66 \%(27)$ & $44 \%(4)$ \\
\hline & blaSHV & $2 \%(1)$ & $11 \%(1)$ \\
\hline & blaOXA-1 & $17 \%(7)$ & $22 \%(2)$ \\
\hline \multirow{5}{*}{ Extended Spectrum Beta-Lactams } & blaFOX & 0 & 0 \\
\hline & blaDHA & 0 & 0 \\
\hline & blaCIT & $2 \%(1)$ & $33 \%(3)$ \\
\hline & blaEBC & 0 & 0 \\
\hline & blaCTXM-8/25 & 0 & 0 \\
\hline
\end{tabular}

PCR screening of ARGs of multidrug-resistant Listeria spp. (MDRL) revealed that among the ARGs responsible for sulfonamide resistance, only sulI was detected in $71 \%$ (29/41) of L. monocytogenes and 67\% (6/9) of L. welshimeri. Tetracyclines tet A was greatly abundant in L. welshimeri by 78\% (7/9) and 63\% (26/41) of L. monocyotgenes harbored tet $A$ gene; tet $B$, tet $C$, and tet $M$ were not detected amongst the Listeria spp. Furthermore, resistance gene catII was present in very low levels, with resistance proportions of $7 \%$ (3/41) amongst L. monocytogenes and no phenicol-resistance gene was detected amongst L. welshimeri isolates. Among the screened ESBL determinants, bla $a_{T E M}$ was the most dominant resistance genes with $L$. monocyotgenes isolates displaying great $b l a_{T E M}$ presence of $66 \%(27 / 41)$ compared to L. welshimeri with $44 \%$ (4/9); bla OXA-1 followed with $17 \%$ 
(7/41) and 22\% (2/9) amongst L. monocytogenes and L. welshimeri isolates, respectively. L. welshimeri displayed 33\% (3/9) bla $a_{C I T}$ resistance. Supplementary Figures S4 and S5 represent the PCR amplicons of the amplification of sull gene and tet A gene, respectively.

\section{Discussion}

The emergence of MDRL poses a serious public health threat to humanity. In this study, our findings provide evidence that the environmental waters of the ECP are probable reservoirs of highly pathogenic Listeria spp. harboring ARGs. The standard plate count of the presumptive Listeria isolates recovered from the selected sample sites was high and this is in accordance with the findings reported by Bilung et al. [7] and Iwu and Okoh [47]. The South African standard guidelines for domestic and irrigation water use are not specific for bacterial concentration. Based on the potable drinking water and irrigation water quality guidelines set by the South African Department of Water Affairs (DWAF) and World Health Organization (WHO) which is $\leq 1-1000$ CFU / $100 \mathrm{~mL}$ of fecal coliforms [48-50], the standard plate counts observed in this study exceeded the acceptable limits. This may be as a result of fecal contamination due to the function of the river as a receiving watershed or run-off from nearby farms involved in animal husbandry. However, in this study, results showed no occurrence of Listeria spp. in the irrigation water samples.

Globally, several studies have also investigated the prevalence of L. monocytogenes present in river and irrigation waters. In the United States, L. monocytogenes was reported in 43\% (604/1405) [51] and 31\% (53/170) [52] of water samples collected from river and irrigation waters. Furthermore, the bacterium has also been isolated from water samples collected from the point of sewage discharge (into a river) in Europe [53]. The study of Manjur et al. [54] carried out in Bangladesh also investigated the distribution of Listeria spp. confirming the occurrence of the microorganisms in soil and surface water samples. In this study, the percentage occurrences (PO) observed was 55.7\% for Listeria species and $59.4 \%$ for L. monocytogenes, while the PO of L. welshimeri (13\%) was much lower. Similarly, other studies reported Listeria spp. with PO of 64\% [7] and 33.30\% [55], which were recovered from surface water bodies (in Canada) and environmental samples (in Malaysia), respectively. Contrary to our findings, another recent study by Iwu and Okoh [47] reported low PO of L. monocytogenes (14\%) recovered from irrigation water in ECP, South Africa.

The patterns of phenotypic resistance exhibited by Listeria spp. in this study revealed that $86.7 \%$ of the isolates displayed MDR against the test antibiotics. In contrast, previous studies reported high susceptibility to penicillin, ampicillin, and tetracycline exhibited by L. monocytogenes recovered from pork and slaughterhouses in Brazil [8] and in retail raw food in China [56], respectively. The ineffectiveness of penicillin against $L$. monocytogenes observed in this study agrees with another study of Aras and Ardıç [9], which reported L. monocytogenes isolated from turkey and meat samples with resistance percentage of $75 \%$ and $66.7 \%$ to ampicillin and penicillin, respectively. In contrast, the findings of this study revealed resistance exhibited by L. monocytogenes against the beta-lactams ampicillin, penicillin, and cephalothin. Similarly, Olaniran et al. [15] reported resistance against penicillin exhibited by Listeria spp. isolated from treated wastewater (WW) final effluents and receiving watersheds.

The Listeria spp. in this study exhibited varied susceptibility to amikacin and gentamicin (aminoglycoside class). Likewise, our finding is corroborated by the study of Bilung et al. [7], who revealed effective activity of gentamicin against Listeria isolates that were recovered from environmental samples collected from farms in Malaysia. Generally, Listeria spp. have been reported to be susceptible to a wide range of antibiotics. However, many studies have reported Listeria spp. exhibiting phenotypic resistance against antibiotics used in the treatment of listeriosis such as tetracycline, chloramphenicol, and fluoroquinolones [16,17,57].

The MARP patterns observed in this study revealed L. monocytogenes and L. welshimeri isolates displaying four and two MARP patterns, respectively. Contrary to studies by Arslan and Özdemir [58] and Conter et al. [59], where Listeria spp. recovered from homemade 
white cheese and also food processing environments, respectively, were reported to exhibit single-drug resistance, MDR against a range of 13 to 15 test antibiotics was observed in the current study. Evaluation of the MAR index of ARLS revealed a MAR index that varied from 0.8 to 1 (Table 4 ) which is above the arbitrary threshold set by Krumperman [40]. In principle, a MARI value above the set threshold (0.2) suggests that the isolates originate from sources of high antibiotic usage. This may imply that the river waters in this study area are highly contaminated with antibiotics including antibiotic residues (antibiotic resistant bacteria (ARB) and ARGs), or other degradable products. These antibiotics find their way into water bodies via final wastewater effluent discharge, surface runoffs from animal husbandry, agricultural soil upon which manure is used as fertilizer and animal waste from nearby grazing livestock systems [60].

The detection of ARGs harbored by Listeria spp. and the increasing rates of Listeria infections are becoming major concerns to public health [26]. Furthermore, the selective pressure exerted by the exposure of Listeria spp. to antibiotics within an environment niche can increase the transfer of ARGs between Listeria spp. and other bacterial species by self-transferable plasmids $[16,17]$. The confirmed Listeria spp. were screened for 24 relevant ARGs, out of which only 7 (29.2\%) ARGs (sull, tet $A$, and ESBL) were detected. Our findings revealed that among the ARGs detected, sulI (which confers AR against sulphonamides) was the most dominant amongst the Listeria spp., particularly L. monocytogenes. Another dominant ARG was tet $A$, which confers resistance against tetracycline, followed by bla $a_{T E M}$ among L. monocytogenes (66\%) and L. welshimeri (44\%) isolates (Table 5). Similarly, Srinivasan et al. [25] reported a low frequency of ARGs harbored by L. monocytogenes recovered from dairy milk farms. Among the ARGs reported included tetA (32\%), and sulI (16\%). However, other tetracycline resistance genes screened were not found to be harboured by L. monocytogenes [25].

In this study, most of the confirmed Listeria spp. that exhibited phenotypic resistance did not harbor ARGs. For instance, all L. monocytogenes and L. welshimeri exhibited phenotypic resistance against chloramphenicol. However, only $7 \%$ of L. monocytogenes harbored catII gene. A low percentage occurrence against aminoglycosides was observed; however, the screened Listeria spp. did not harbor ARG. Other studies of Davis and Jackson [23] and Morvan et al. [61] also reported Listeria isolates exhibiting phenotypic resistance against aminoglycosides but did not harbor ARGs.

There is insufficient information concerning the occurrence of ESBLs encoding genes harbored by Listeria spp. and this is among the few studies reporting the detection of ESBLs encoding genes harbored by Listeria spp. recovered from the aquatic environment in South Africa.

\section{Conclusions}

The findings of this current study revealed the presence of Listeria spp. in river water and irrigation water samples. All the confirmed Listeria spp. exhibited multidrug resistance (MDR) and harbored more than one ARG. The occurrence of MDR strains of L. monocytogenes in the water samples indicates that the bacteria are most likely to be transferred to other ecosystems. The ARGs harbored by the Listeria spp. are most likely to be transferred to other bacterial species within the aquatic environment. Therefore, this poses a significant public health risk and environmental crisis that involves the spread of ARB. Therefore, more comprehensive monitoring of the nature of acquisition and spread of ARGs among Listeria spp. is needed particularly in the agroecosystem. The final effluent from WWTPs should also be appropriately depurated before discharge into receiving water bodies.

Supplementary Materials: The following are available online at https:/ /www.mdpi.com/1660-4 601/18/2/481/s1, Figure S1. PCR products of the amplification of prs gene. Lane 1-8: positive Listeria spp. isolates; Lane M: 100 bp molecular weight marker (ThermoFisher ${ }^{\mathrm{TM}}$ Scientific, (EU) Lithuana); Lane N: negative PCR control (no DNA). Figure S2. PCR products of the amplification of prfA gene. Lane 1-11: positive L. monocytogenes isolates; Lane M: 100 bp molecular weight marker 
(ThermoFisher ${ }^{\mathrm{TM}}$ Scientific, (EU) Lithuana); Lane N: negative PCR control (no DNA). Figure S3. PCR products of the amplification of 16S rRNA gene. Lane 1-9: positive L. welshimeri isolates; Lane M: 100 bp molecular ladder (ThermoFisher ${ }^{\mathrm{TM}}$ Scientific, (EU) Lithuana); Lane N: negative PCR control (no DNA). Figure S4. PCR products of the amplification of sulI gene. Lane 1-9: Listeria isolates that harbour sulI gene (822 bp); lane M: 100 bp molecular weight marker (ThermoFisher ${ }^{\text {TM }}$ Scientific, (EU) Lithuana); Lane N: negative PCR control (no DNA). Figure S5. PCR products of the amplification of tetA gene. Lane 1-12: Listeria isolates that harbour tet A gene (201 bp); lane M: 100 bp molecular weight marker (ThermoFisher ${ }^{\mathrm{TM}}$ Scientific, (EU) Lithuana); Lane N: negative PCR control (no DNA).

Author Contributions: L.M. conceived the study and was involved in the design and coordination of the study and manuscript, interpretation of data and critical review of draft manuscript for intellectual content. A.I.O. was involved in supervision and acquisition of resources and funding for the study. L.M., K.E.E. and A.I.O. were involved in the final editing of the manuscript. All authors have read and agreed to the published version of the manuscript.

Funding: This research was supported by South African Medical Research Council (SAMRC). The National Research Foundation of South Africa provided study scholarship to L.M.

Institutional Review Board Statement: Not applicable.

Informed Consent Statement: Not applicable.

Data Availability Statement: Data sharing not applicable.

Acknowledgments: The authors acknowledge South African Medical Research Council and National Research Foundation (NRF) for financial support.

Conflicts of Interest: The authors declare that they have no conflict of interest.

\section{References}

1. Orsi, R.H.; Wiedmann, M. Characteristics and distribution of Listeria spp., including Listeria species newly described since 2009. Appl. Microbial. Biotechnol. 2016, 100, 5273-5287. [CrossRef] [PubMed]

2. Kayode, A.J.; Igbinosa, E.O.; Okoh, A.I. Overview of listeriosis in the Southern African Hemisphere. J. Food Saf. 2020, 40 , e12732. [CrossRef]

3. Leclercq, A.; Moura, A.; Vales, G.; Tessaud-Rita, N.; Aguilhon, C.; Lecuit, M. Listeria thailandensis sp. nov. Int. J. Syst. Evol. Microbiol. 2019, 69, 74-81. [CrossRef] [PubMed]

4. Sauders, B.D.; Overdevest, J.; Fortes, E.; Windham, K.; Schukken, Y.; Lembo, A.; Wiedmann, M. Diversity of Listeria species in urban and natural environments. Appl. Environ. Microbiol. 2012, 78, 4420-4433. [CrossRef] [PubMed]

5. Vivant, A.L.; Garmyn, D.; Piveteau, P. Listeria monocytogenes, a down-to-earth pathogen. Front. Cell. Infect. Microbiol. $2013,3,87$. [CrossRef] [PubMed]

6. $\quad$ Linke, K.; Rückerl, I.; Brugger, K.; Karpiskova, R.; Walland, J.; Muri-Klinger, S.; Tichy, A.; Wagner, M.; Stessl, B. Reservoirs of Listeria species in three environmental ecosystems. Appl. Environ. Microbiol. 2014, 80, 5583-5592. [CrossRef]

7. Bilung, L.; Sin Chai, L.; Tahar, A.S.; Ted, C.K.; Apun, K. Prevalence, genetic heterogeneity, and antibiotic resistance profile of Listeria spp. and Listeria monocytogenes at farm level: A highlight of ERIC-and BOX-PCR to reveal genetic diversity. Biomed Res. Int. 2018, 1-12. [CrossRef]

8. Moreno, L.Z.; Paixão, R.; Gobbi, D.D.; Raimundo, D.C.; Ferreira, T.P.; Moreno, A.M.; Hofer, E.; Reis, C.M.; Matté, G.R.; Matté, M.H. Characterization of antibiotic resistance in Listeria spp. isolated from slaughterhouse environments, pork and human infections. Infect. Dev. Ctries. 2014, 8, 416-423. [CrossRef]

9. Aras, Z.; Ardıç, M. Occurrence and antibiotic susceptibility of Listeria species in turkey meats. Food Sci. Anim. Resour. 2015, 35, 669. [CrossRef]

10. Liu, H.; Lu, L.; Pan, Y.; Sun, X.; Hwang, C.A.; Zhao, Y.; Wu, V.C. Rapid detection and differentiation of Listeria monocytogenes and Listeria species in deli meats by a new multiplex PCR method. Food Control 2015, 52, 78-84. [CrossRef]

11. Şanlıbaba, P.; Tezel, B.U.; Çakmak, G.A. Prevalence and antibiotic resistance of Listeria monocytogenes isolated from ready-to-eat foods in Turkey. J. Food Qual. 2018, 1-9. [CrossRef]

12. Odjadjare, E.E.; Obi, L.C.; Okoh, A.I. Municipal wastewater effluents as a source of listerial pathogens in the aquatic milieu of the Eastern Cape Province of South Africa: A concern of public health importance. IJERPH 2010, 7, 2376-2394. [CrossRef] [PubMed]

13. Odjadjare, E.E.; Okoh, A.I. Prevalence and distribution of Listeria pathogens in the final effluents of a rural wastewater treatment facility in the Eastern Cape Province of South Africa. World J. Microbiol. Biotechnol. 2010, 26, 297-307. [CrossRef]

14. Taherkhani, A.; Attar, H.M.; Moazzam, M.M.; Mirzaee, S.A.; Jalali, M. Prevalence of Listeria monocytogenes in the river receiving the effluent of municipal wastewater treatment plant. J. Environ. Health Sci. 2013, 2, 49. 
15. Olaniran, A.O.; Nzimande, S.B.; Mkize, N.G. Antimicrobial resistance and virulence signatures of Listeria and Aeromonas species recovered from treated wastewater effluent and receiving surface water in Durban, South Africa. BMC Microbiol. 2015, 5, 234. [CrossRef]

16. Luque-Sastre, L.; Arroyo, C.; Fox, E.M.; McMahon, B.J.; Bai, L.; Li, F.; Fanning, S. Antimicrobial resistance in listeria species. In Antimicrobial Resistance in Bacteria from Livestock and Companion Animals; ASM: Washington, DC, USA, 2018; pp. 237-259.

17. Olaimat, A.N.; Al-Holy, M.A.; Shahbaz, H.M.; Al-Nabulsi, A.A.; Abu Ghoush, M.H.; Osaili, T.M.; Ayyash, M.M.; Holley, R.A. Emergence of antibiotic resistance in Listeria monocytogenes isolated from food products: A comprehensive review. Compr. Rev. Food Sci. Food Saf. 2018, 17, 1277-1292. [CrossRef]

18. WHO (World Health Organization). Listeriosis. Available online: https://www.who.int/news-room/fact-sheets/detail/ listeriosis (accessed on 30 July 2020).

19. Bhunia, A.K. Foodborne Microbial Pathogens: Mechanisms and Pathogenesis. Food Sci. Texts 2008, Ł42, 50.

20. Buchanan, R.L.; Gorris, L.G.; Hayman, M.M.; Jackson, T.C.; Whiting, R.C. A review of Listeria monocytogenes: An update on outbreaks, virulence, dose-response, ecology, and risk assessments. Food Control 2017, 75, 1-3. [CrossRef]

21. Jemmi, T.; Stephan, R. Listeria monocytogenes: Food-borne pathogen and hygiene indicator. Rev. Sci. Tech. 2006, 25, 571-580. [CrossRef]

22. Wilson, A.; Gray, J.; Chandry, P.S.; Fox, E.M. Phenotypic and genotypic analysis of antimicrobial resistance among Listeria monocytogenes isolated from Australian food production chains. Genes 2018, 9, 80. [CrossRef]

23. Davis, J.A.; Jackson, C.R. Comparative antimicrobial susceptibility of Listeria monocytogenes, L. innocua, and L. welshimeri. Microb. Drug Resist. 2009, 15, 27-32. [CrossRef] [PubMed]

24. Chen, M.; Chen, Y.; Wu, Q.; Zhang, J.; Cheng, J.; Li, F.; Zeng, H.; Lei, T.; Pang, R.; Ye, Q.; et al. Genetic characteristics and virulence of Listeria monocytogenes isolated from fresh vegetables in China. BMC Microbiol. 2019, 19, 119. [CrossRef] [PubMed]

25. Srinivasan, V.; Nam, H.M.; Nguyen, L.T.; Tamilselvam, B.; Murinda, S.E.; Oliver, S.P. Prevalence of antimicrobial resistance genes in Listeria monocytogenes isolated from dairy farms. Foodborne Pathog. Dis. 2005, 2, 201-211. [CrossRef] [PubMed]

26. Li, Q.; Sherwood, J.S.; Logue, C.M. Antimicrobial resistance of Listeria spp. recovered from processed bison. Lett. Appl. Microbiol. 2007, 44, 86-91. [CrossRef]

27. Centers for Disease Control and Prevention (CDC). Antibiotic Resistant Threats in the United States. 2019. Available online: https:/ / www.cdc.gov/drugresistance/pdf/threats-report/2019-ar-threats-report-508.pdf (accessed on 28 December 2020).

28. Centers for Disease Control and Prevention (CDC). Multistate Outbreak of Listeriosis Linked to Whole Cantaloupes from Jensen Farms, Colorado. Centers for Disease Control and Prevention, Atlanta, 2012. Available online: http:/ / www.cdc.gov/listeria/ outbreaks / cantaloupes-jensen-farms/index.html (accessed on 26 March 2020).

29. Centers for Disease Control and Prevention (CDC). Outbreak of Listeria Infections Linked to Enoki Mushrooms, Republic of Korea. 2020. Available online: https:/ / www.cdc.gov/listeria/outbreaks/enoki-mushrooms-03-20/index.html (accessed on 18 June 2020).

30. National Institute of Communicable Diseases (NCID). Situation Update Listeriosis Outbreak, South Africa. Available online: http:/ / www.nicd.ac.za/wp-content/uploads/2018/04/NICD-Situation-update-on-listeriosis-outbreak-South-Africa_13 -April-2018.pdf (accessed on 28 November 2019).

31. Desai, A.N.; Anyoha, A.; Madoff, L.C.; Lassmann, B. Changing epidemiology of Listeria monocytogenes outbreaks, sporadic cases, and recalls globally: A review of ProMED reports from 1996 to 2018. IJID 2019, 84, 48-53. [CrossRef]

32. Centre for Disease Control and Prevention (CDC). Listeriosis. Available online: https://www.cdc.gov/onehealth/index.html\#: $\sim\{\}$ :text=One $\% 20$ Health $\% 20$ is $\% 20$ a $\% 20$ collaborative,plants $\% 2 C \% 20$ and $\% 20$ their $\% 20$ shared $\% 20$ environment (accessed on 31 December 2020).

33. International Organization for Standardization (ISO 11290-1). Microbiology of Food and Animal Feeding Stuffs: Horizontal Method for the Detection of Listeria Monocytogenes. Part 1: Detection Methods. Available online: https://www.iso.org (accessed on 5 January 2021).

34. Du Plessis, E.M.; Duvenage, F.; Korsten, L. Determining the potential link between irrigation water quality and the microbiological quality of onions by phenotypic and genotypic characterization of Escherichia coli isolates. J. Food Prot. 2015, 78, 643-651. [CrossRef]

35. Maugeri, T.L.; Carbone, M.; Fera, M.T.; Irrera, G.P.; Gugliandolo, C. Distribution of potentially pathogenic bacteria as free living and plankton associated in a marine coastal zone. J. Appl. Microbiol. 2004, 97, 354-361. [CrossRef] [PubMed]

36. Doumith, M.; Buchrieser, C.; Glaser, P.; Jacquet, C.; Martin, P. Differentiation of the major Listeria monocytogenes serovars by multiplex PCR. J. Clin. Microbiol. 2004, 42, 3819-3822. [CrossRef]

37. Jami, S.; Jamshidi, A.; Khanzadi, S. The presence of Listeria monocytogenes in raw milk samples in Mashhad, Iran. Iran. J. Vet. Res. 2010, 11, 363-367.

38. Clinical and Laboratory Standards Institute. Performance Standards for Antimicrobial Susceptibility Testing; Fifteenth Informational Supplement, M100-S15; CLSI: Wayne, PA, USA, 2018.

39. Obaidat, M.M.; Bani Salman, A.E.; Lafi, S.Q.; Al-Abboodi, A.R. Characterization of Listeria monocytogenes from three countries and antibiotic resistance differences among countries and Listeria monocytogenes serogroups. Lett. Appl. Microbiol. 2015, 60, 609-614. [CrossRef]

40. Krumperman, P.H. Multiple antibiotic resistance indexing of Escherichia coli to identify high-risk sources of fecal contamination of foods. Appl. Environ. Microbiol. 1983, 46, 165-170. [CrossRef] 
41. Dallenne, C.; Da Costa, A.; Decré, D.; Favier, C.; Arlet, G. Development of a set of multiplex PCR assays for the detection of genes encoding important $\beta$-lactamases in Enterobacteriaceae. J. Antimicrob. Chemother. 2010, 65, 490-495. [CrossRef] [PubMed]

42. Maynard, C.; Bekal, S.; Sanschagrin, F.; Levesque, R.C.; Brousseau, R.; Masson, L.; Larivière, S.; Harel, J. Heterogeneity among virulence and antimicrobial resistance gene profiles of extraintestinal Escherichia coli isolates of animal and human origin. J. Clin. Microbiol. 2004, 42, 5444-5452. [CrossRef]

43. Falbo, V.; Carattoli, A.; Tosini, F.; Pezzella, C.; Dionisi, A.M.; Luzzi, I. Antibiotic resistance conferred by a conjugative plasmid and a class I integron in Vibrio cholerae O1 El Tor strains isolated in Albania and Italy. Antimicrob. Agents Chemother. 1999, 43, 693-696. [CrossRef]

44. Srinivasan, V.; Gillespie, B.E.; Lewis, M.J.; Nguyen, L.T.; Headrick, S.I.; Schukken, Y.H.; Oliver, S.P. Phenotypic and genotypic antimicrobial resistance patterns of Escherichia coli isolated from dairy cows with mastitis. Vet. Microbiol. 2007, 124, 319-328. [CrossRef]

45. Bailey, J.K.; Pinyon, J.L.; Anantham, S.; Hall, R.M. Commensal Escherichia coli of healthy humans: A reservoir for antibioticresistance determinants. J. Med. Microbiol. 2010, 59, 1331-1339. [CrossRef] [PubMed]

46. Ng, L.K.; Martin, I.; Alfa, M.; Mulvey, M. Multiplex PCR for the detection of tetracycline resistant genes. Mol. Cell. Probes 2001, 15, 209-215. [CrossRef]

47. Iwu, C.D.; Okoh, A.I. Characterization of antibiogram fingerprints in Listeria monocytogenes recovered from irrigation water and agricultural soil samples. PLoS ONE 2020, 15, e0228956. [CrossRef] [PubMed]

48. WHO (World Health Organisation). Health guidelines for the use of wastewater in agriculture and aquaculture. In Technical Report Series 778; World Health Organisation: Geneva, Switzerland, 1989.

49. DWAF (Department of Water Affairs and Forestry). South African Water Quality Guidelines, 2nd ed.; Agricultural Use: Irrigation. Produced by the CSIR Environmental Services: Pretoria; The Government Printer: Pretoria, South Africa, 1996 ; Volume 4.

50. South African National Standard (SANS 241). Drinking Water Part 1: Microbiological, Physical, Aesthetic and Chemical Determinants; SABS Standards Division Publications: Pretoria, South Africa, 2015.

51. Cooley, M.B.; Quiñones, B.; Oryang, D.; Mandrell, R.E.; Gorski, L. Prevalence of Shiga toxin producing Escherichia coli, Salmonella enterica, and Listeria monocytogenes at public access watershed sites in a California Central Coast agricultural region. Front. Cell. Infect. Microbiol. 2014, 4, 30. [CrossRef] [PubMed]

52. Sharma, M.; Handy, E.T.; East, C.L.; Kim, S.; Jiang, C.; Callahan, M.T.; Allard, S.M.; Micallef, S.; Craighead, S.; Anderson-Coughlin, B.; et al. Prevalence of Salmonella and Listeria monocytogenes in non-traditional irrigation waters in the Mid-Atlantic United States is affected by water type, season, and recovery method. PLoS ONE 2020, 15, e0229365. [CrossRef] [PubMed]

53. Czeszejko, K.; Boguslawska-Was, E.; Dabrowski, W.; Kaban, S.; Umanski, R. Prevalence of Listeria monocytogenes in municipal and industrial sewage. Electron. J. Pol. Agric. Univ. Environ. Dev. 2003, 6. Available online: https:/ /www.ejpau.media.pI (accessed on 5 January 2021).

54. Manjur, M.S.E.; Siddique, S.; Ahmed, S. Multi-drug resistant pathogenic Listeria monocytogenes in surface water and soil samples of Dhaka city. Bangladesh J. Microbiol. 2016, 33, 39-42. [CrossRef]

55. Lyautey, E.; Lapen, D.R.; Wilkes, G.; McCleary, K.; Pagotto, F.; Tyler, K.; Hartmann, A.; Piveteau, P.; Rieu, A.; Robertson, W.J.; et al. Distribution and characteristics of Listeria monocytogenes isolates from surface waters of the South Nation River watershed, Ontario, Canada. Appl. Environ. Microbiol. 2007, 73, 5401-5410. [CrossRef] [PubMed]

56. $\mathrm{Wu}, \mathrm{S}$.; $\mathrm{Wu}, \mathrm{Q} . ; \mathrm{Zhang}, \mathrm{J} . ;$ Chen, $\mathrm{M}$.; Hu, H. Listeria monocytogenes prevalence and characteristics in retail raw foods in China. PLoS ONE 2015, 10, e0136682. [CrossRef] [PubMed]

57. Lungu, B.; O’Bryan, C.A.; Muthaiyan, A.; Milillo, S.R.; Johnson, M.G.; Crandall, P.G.; Ricke, S.C. Listeria monocytogenes: Antibiotic resistance in food production. Foodborne Pathog. Dis. 2011, 8, 569-578. [CrossRef] [PubMed]

58. Arslan, S.; Özdemir, F. Prevalence and antimicrobial resistance of Listeria spp. in homemade white cheese. Food Control 2008, 19, 360-363. [CrossRef]

59. Conter, M.; Paludi, D.; Zanardi, E.; Ghidini, S.; Vergara, A.; Ianieri, A. Characterization of antimicrobial resistance of foodborne Listeria monocytogenes. Int. J. Food Microbiol. 2009, 128, 497-500. [CrossRef]

60. Iwu, C.D.; Okoh, A.I. Preharvest Transmission Routes of Fresh Produce Associated Bacterial Pathogens with Outbreak Potentials: A Review. IJERPH 2019, 16, 4407. [CrossRef] [PubMed]

61. Morvan, A.; Moubareck, C.; Leclercq, A.; Hervé-Bazin, M.; Bremont, S.; Lecuit, M.; Courvalin, P.; Le Monnier, A. Antimicrobial resistance of Listeria monocytogenes strains isolated from humans in France. Antimicrob. Agents Chemother. 2010, 54, 2728-2731. [CrossRef] 